Brit. J. industr. Med., 1951, 8, 302

\title{
CARCINOMA OF THE LUNG IN CHROMATE WORKERS*
}

\author{
BY \\ P. LESLEY BIDSTRUP \\ From the Department for Research in Industrial Medicine, Medical \\ Research Council, the London Hospital
}

In a review of the literature on carcinoma of the respiratory system occurring in persons exposed in their work to chromates Baetjer (1950) found 122 recorded cases. Of these 109 worked in the chromate-producing industry, 11 in the manufacture of chrome pigments, and two in other industries where chromium compounds are used. Sixty-three of the cases occurred in Germany, 57 in the United States of America, one in Switzerland, and one in Great Britain. In the majority the primary growth was in the lung. The case reported from Great Britain by Newman (1890) was one of adrenocarcinoma of the nares in a chrome worker aged 47. The septum of his nose had become perforated 20 years previously, and the patient stated that many of his fellow-workmen were similarly affected. In his description of the findings in this case Newman emphasizes that the nasal septum was not involved in the carcinomatous change. He states : "... on examination a large rounded perforation was seen in the nasal septum, large enough to allow a shilling to pass from one nostril to the other. The margins of the perforation were smooth, completely cicatrized, pale in colour and free from ulceration. The anterior margin of the perforation is situated about half an inch from the top of the nose. . . . The tumour occupied the anterior half of the left nostril and almost touched the septum. It was firmly attached to the inferior turbinate and caused some displacement of the nasal bones". Legge (1922) reported that he could find no evidence of epitheliomatous change in 175 cases of chrome ulceration.

Machle and Gregorius (1948) studied the causes of death among workers in the chromate-producing industry in the United States of America. They concluded that the proportion of deaths due to carcinoma of the respiratory system was 16 times the expected proportion. The crude death rate

\footnotetext{
* Report of an investigation in the chromate-producing industry in Great Britain."
}

for carcinoma of the lung was 25 times the normal. Baetjer (1950) confirmed these findings for the industry in the United States of America in a study based on the records from two Baltimore hospitals, each of them near a chromate-producing factory. Since neither mortality data nor reliable information regarding former employees were available for any of the three factories making basic chromates from the ore chromite in Great Britain, a search for cases of carcinoma of the lung was made among workers employed in the industry in 1949. Although this was the only method of investigation which could be adopted in the circumstances, it has the limitation that no definite conclusions as to the incidence of carcinoma of the lung in chromate workers in Great Britain can be drawn from the findings unless these are confirmed in a follow-up study.

\section{Method of Investigation}

Seven hundred and twenty-four workers were interviewed and radiographs of the chest were taken on $14 \times 17$ in. films. In addition, 31 workers were interviewed but not radiographed. Works lists furnished before the survey began gave the names of 588 employees. In addition, 198 workmen whose names were not included in the original works lists, but who were employed on the manufacture of basic chromate, attended for $x$-ray examination, making the total number of workmen at risk 786. Twenty-one of these had left the works before the survey began, and four were sick during the survey. The total number of workmen exposed to chromium compounds in these factories at the time of the survey was therefore 765. Six men declined both interview and $x$-ray examination (Table 1).

The investigation included a personal interview with each employee at his place of work. Present and past occupations were recorded together with a clinical history which included specific enquiry for symptoms such as cough, dyspnoea, and pain in the chest. In persons in whom the clinical history or general appearance was suggestive of ill-health, and in all cases where an abnormality was detected in the radiograph of the chest, a complete clinical examination was made. The 
TABle 1

CLINICAL AND RADIOGRAPHIC SURVEY OF WORKERS IN THE CHROMATE-PRODUCING INDUSTRY IN GREAT BRITAIN

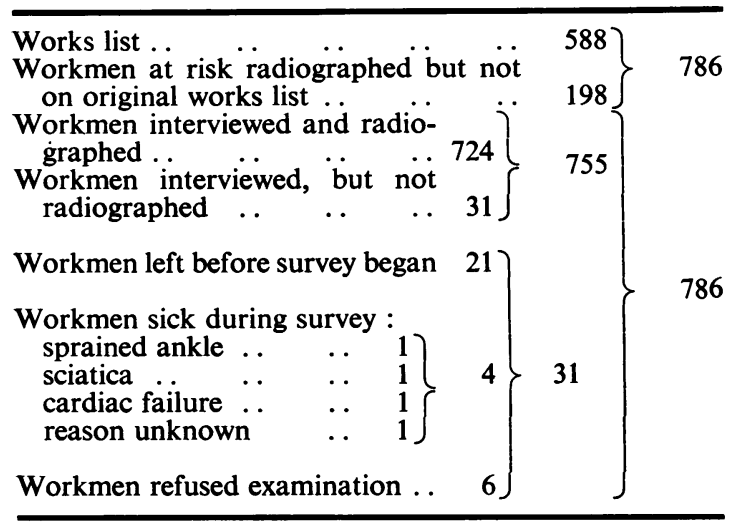

films were read by two physicians, and each film was looked at on two occasions at an interval of at least one week. In doubtful cases the opinion of a radiologist was obtained and findings confirmed by further investigation. Environmental conditions were investigated in each factory to determine the possible exposure to chromium compounds in the various jobs in the process. The results of the environmental study are reported in an accompanying paper by Buckell and Harvey.

\section{Description of the Process}

Metallic chromium and the chromium compounds used in industry are obtained from the basic chromates, sodium and potassium dichromate or monochromate. These compounds are prepared from the ferrous ore, chromite or chrome ironstone $\mathrm{FeO} \mathrm{Cr}{ }_{2} \mathrm{O}_{3}$. The ore contains from 40 to $50 \%$ of chromium, and alumina and silica are present as impurities. The ore is dried, crushed, mixed with limestone and the carbonate either of sodium or of potassium, and heated in a rotary furnace for eight hours at a temperature of $1200^{\circ} \mathrm{C}$. In many factories throughout the world the introduction of rotary furnaces to replace reverbatory furnaces has taken place only in the last decade. The oxide is converted to monochromate, and the frit from the furnace is carried to washing or leaching tanks arranged in series. The monochromate is dissolved out by repeated washings with water, and the concentrated liquor containing monochromate is treated with sulphuric acid. Dichromate is formed by double decomposition and sodium sulphate is a by-product. The process is the same in the three factories in Great Britain, but there are differences in the lay-out of the works and in the type of equipment. In most factories in the United States of America and in Germany roasting of the ore is done in two stages. In the second stage residue from the leaching tanks is dried and crushed and used as a filler in place of limestone. This residue contains as much as $1 \%$ of monochromate. In the factories in Great Britain the residue from the leaching tanks is discarded in a moist condition and carried to dumps outside the factory.

Buckell and Harvey (q.v.) report the results of the sampling of atmosphere in chromate-producing factories in Great Britain, and compare the findings with those recorded in a factory in the United States of America by Bourne and Yee in 1950. Concentrations of both soluble and insoluble chromates were found to be much higher in the atmosphere of the factories in Great Britain than in the factory studied by Bourne and Yee.

\section{Results of Clinical Investigation}

Three hundred and six of the 724 workmen examined were over the age of 44 , and of these 131 were more than 60 years of age. The average age was $\mathbf{4 4 . 3}$ years (Table 2). It is the custom in all three factories for employees to work on different stages of the process from time to time. This fact and the conditions in the factory due to variations in ventilation, temperature, and humidity make it impossible to assess the exposure to chromates of individual workmen. Two hundred and thirty-seven of the 724 persons examined had been employed in the chromate-producing industry for more than 15 years; of these, 165 had worked in the industry for more than 20 years. The average duration of exposure to soluble and insoluble chromates in the working atmosphere was $12 \cdot 2$ years (Table 3).

One case of carcinoma of the lung was found among the 724 workers interviewed and radiographed. This occurred in a man aged 59 who was interviewed on August 22, $1949 . \quad \mathrm{He}$ had been employed as a process worker on the manufacture of bichromate of ammonia for eight months. Twenty years previously he had worked in the crystal-house in the same factory for six years. He had experienced chrome ulceration of the skin on both occasions. At the interview he complained of dyspepsia including flatulence and loss of appetite. $\mathrm{He}$ had been treated in the past for duodenal ulcer. Although all workers who were interviewed were asked particularly about such symptoms as cough, dyspnoea, and pain in the chest, this man complained of no symptoms suggesting disease of the respiratory system. He weighed 9 st. $12 \mathrm{lb}$., and he stated that this was his usual weight. A radiograph of the chest on September 14, 1949, revealed enlargement of the hilar shadow on the right side, and a diagnosis of carcinoma of the lung was made at 
TABLE 2

ANALYSIS INTO AGE GROUPS

\begin{tabular}{c|c}
\hline Age in Years & $\begin{array}{c}\text { Number of } \\
\text { Workmen }\end{array}$ \\
\hline $15-$ & 45 \\
$25-$ & 151 \\
$35-$ & 219 \\
$45-$ & 175 \\
60 and over & 131 \\
age unknown & 3 \\
\hline
\end{tabular}

Average age $=44.3$ years

Number of workmen over 44 years $=306$

TABLE 3

DURATION OF EXPOSURE TO CHROMATES

\begin{tabular}{c|c}
\hline Years & $\begin{array}{c}\text { Number of } \\
\text { Workmen }\end{array}$ \\
\hline Less than one & 82 \\
$1-4$ & 211 \\
$5-9$ & 110 \\
$10-14$ & 84 \\
$15-19$ & 72 \\
$20-24$ & 41 \\
$25-29$ & 41 \\
$30-34$ & 35 \\
$35-39$ & 21 \\
$40-44$ & 13 \\
$45-49$ & 9 \\
50 and over & 5 \\
\hline
\end{tabular}

Average duration of exposure $=12 \cdot 2$ years

More than 15 years in chromate-producing industry $=237$ More than 20 years in chromate-producing industry $=165$

this time. He was admitted to hospital on November 26, 1949, and died shortly after admission. At necropsy, carcinoma of the bronchus to the right upper lobe with secondary deposits in the lung, mediastinal glands, liver, and vertebrae were found. In addition there was a chronic pyloric ulcer which had perforated causing acute general peritonitis. The history of this man's terminal illness was obtained from a brother. The patient had been ill for 11 weeks before being admitted to hospital on the day of his death. He complained only of pain in the back, and thought he had strained his back at work. There was a striking loss of weight from $9 \mathrm{st} .12 \mathrm{lb}$. in August to $8 \mathrm{st} .4 \mathrm{lb}$. at the time of his death three months later.

Active pulmonary tuberculosis was found in 17 of the 724 workmen radiographed, and healed lesions in the lung parenchyma in four. One case of mitral stenosis with venous congestion of the lungs, and one of dextrocardia were revealed. A man aged 71, who had worked in the industry for 35 years, died from heart failure during the survey. There is no reason to believe that death was due to disease of the respiratory system.

A follow-up enquiry by letter 13 months after the survey was completed disclosed that four workmen who had taken part in the investigation had died. In one of these death was due to carcinoma of the lung. An attempt is being made to observe for a further period of two years the incidence of carcinoma of the respiratory system among the workmen examined in 1949.

\section{Discussion}

Kennaway and Kennaway (1947) record that the incidence of carcinoma of the lung in men in England and Wales between the years 1921 and 1945 has increased sixteenfold. They were unable to find any particular occupation among 63 studied to which this increase could be attributed. The sources of error in statistical work based on a study of death certificates are discussed, and include the large sampling error which is inevitable when small numbers of men are employed in a particular occupation. Relatively few men are engaged in the chromate-producing industry, and it may be difficult to prove by statistical methods that the incidence among them of a common disease such as carcinoma of the lung is abnormally high (Bidstrup, 1950).

Examination by mass radiography of 724 employees in the chromate-producing industry in Great Britain revealed only one case of lung carcinoma. This observation may be compared with the results obtained among men in Great Britain in 1949 by mass radiography units of the Ministry of Health. The criteria of diagnosis adopted in this survey are not necessarily the same, nor can the mass radiography units be assumed to have examined an entirely representative cross-section of the population. In spite of these factors, the comparison should provide an approximate indication of the normality of the experience in the chromateproducing industry. Table 4 shows the morbidity rates due to intrathoracic new growths at different ages as determined by the national mass radiography units, and the number of cases of intrathoracic new growths which might therefore have been expected. From Table 4 it is seen that 0.41 cases were expected, whereas, in fact, one was found.

The numbers are clearly too small for any definite conclusions to be drawn from the results of this investigation. The same result could have been obtained whether workers employed in the chromateproducing industry were at particular risk of developing lung carcinoma or not. It is unlikely that the risk would be as great as 25 times the normal as is stated by Machle and Gregorius 
TABLE 4

MORBIDITY RATES AT VARIOUS AGES

\begin{tabular}{|c|c|c|}
\hline $\begin{array}{l}\text { Age in } \\
\text { Years }\end{array}$ & $\begin{array}{c}\text { Incidence of } \\
\text { Intrathoracic * } \\
\text { Malignant Disease } \\
\text { in Males in } \\
\text { Great Britain }\end{array}$ & $\begin{array}{c}\text { Expected Incidence } \\
\text { of Intrathoracic } \\
\text { Malignant Disease } \\
\text { in } 724 \text { workers in the } \\
\text { Chromate-producing } \\
\text { Industry in } \\
\text { Great Britain }\end{array}$ \\
\hline $\begin{array}{r}15- \\
25- \\
35- \\
45- \\
60 \text { and } \\
\text { over }\end{array}$ & $\begin{array}{r}0 \\
2 \\
16 \\
76 \\
186\end{array}$ & $\begin{array}{l}0.0 \\
0.003 \\
0.035 \\
0.133 \\
0.243\end{array}$ \\
\hline All ages & - & 0.414 \\
\hline
\end{tabular}

* Figures obtained from Mass Radiography Report (1949) by permission of Dr. Norman Smith and Dr. Peter Kerley, of the Ministry of Health (rate per 100,000).

(1948) to be the case for workers in this industry in the United States of America.

The hazard would be better assessed by the follow-up over several years of persons at risk, and the comparison of the number of deaths among them due to lung carcinoma with the number expected from the national mortality rates. Table 5 shows the death rates from carcinoma of the lung at different ages as given by the Registrar-General for 1948. The figures for 1949, the year in which the survey was carried out, are not yet available. The number of deaths expected to occur in one year in the population surveyed is also shown in Table 5, and it is seen that 0.44 were expected whereas one occurred. The second death from lung carcinoma among chromate workers examined occurred more than one year after the survey was concluded. The figures are again too small for definite conclusions to be drawn, but it is hoped that a follow-up study over several years will provide data from which the true incidence of carcinoma of the lung in workmen in the chromate-producing industry in Great Britain may be assessed.

\section{Summary and Conclusions}

The results of clinical and $x$-ray examination of workmen employed in the chromate-producing industry in Great Britain are reported.

The processing of chromate in "Great Britain is briefly described, and reference made to the environmental study of the chromate industry by Buckell and Harvey.

One case of pulmonary carcinoma was found on examination by mass radiography of 724 workmen. The total number of workmen exposed to chromates in the chromate-producing industry was not more than 765 at the time that the survey was made.
TABLE 5

CARCINOMA DEATH RATES AS GIVEN BY THE REGISTRARGENERAL IN 1948

\begin{tabular}{c|c|c}
\hline Age & $\begin{array}{c}\text { Death Rate for } \\
\text { Lung Carcinoma } \\
\text { in Males in } \\
\text { England and Wales, } \\
1948 \\
\text { (Rate per 100,000) }\end{array}$ & $\begin{array}{c}\text { Expected Death Rate } \\
\text { for Lung Carcinoma } \\
\text { in 724 Workmen in } \\
\text { Chromate-producing } \\
\text { Industry in } \\
\text { One Year (1949) }\end{array}$ \\
\hline $15-$ & 0.95 & 0.000 \\
$25-$ & 3.43 & 0.005 \\
$35-$ & 16.81 & 0.037 \\
$45-$ & 93.33 & 0.163 \\
$60-69^{*}$ & 177.58 & 0.233 \\
\hline All ages & - & 0.438 \\
\hline
\end{tabular}

* The age group 60-69 includes all men over 60 years of age. Twenty-four of them were over 70 years of age.

The findings are compared with the incidence of intrathoracic new growth among men in the general population in Great Britain obtained by mass radiography units in 1949, and with the death rates from lung carcinoma at different ages as given by the Registrar-General for 1948 .

It is not possible to assess from this investigation the true incidence of carcinoma of the respiratory system among workmen in the chromate-producing industry in Great Britain, but the results suggest that the crude death rate is unlikely to be as great as 25 times the normal.

Since it is possible that there is some increase in the incidence of carcinoma of the lung in workmen employed in this industry in Great Britain, an attempt is being made to follow for a further period of two years the health of men who took part in the investigation in 1949.

Without the cooperation of the management in each of the chromate-producing factories this investigation would not have been possible.

I am indebted to Dr. Richard Doll for assistance in assessing the results of the survey, to Dr. P. B. S. Fowler for seeing with me all the radiographs, and to Dr. Donald Hunter for advice and criticism in carrying out the investigation. Dr. Norman Smith and Dr. Peter Kerley of the Ministry of Health have made available the data on the incidence of carcinoma of the lung which is used for comparison in Table 4. Messrs. H. T. Ferrier and J. Maclagan arranged the $x$-ray examinations.

\section{REFERENCES}

Baetjer, A. M. (1950). Arch, industr. Hyg. occup. Med., 2, 487, 505. Bidstrup, P. L. (1950). Arch. belges Med. soc., 8, 500.

Kennaway, E. L., and Kennaway, N. M. (1947). Brit. J. Cancer, $1,260$.

Legge, T. M. (1922). Brit. med. J., 2, 1110.

Machle, W., and Gregorius, F. (1948). U.S. Pub. Hlth Rep., $63,1114$. Newman, D. A. (1890). Glasgow med. J., 33, 469. 